\title{
SELECTION OF INFORMATIVE COLOR FEATURES OF OBJECT AREAS OF PORK
}

\author{
Ivan Penchev ${ }^{1}$, Stanka Baycheva ${ }^{2}$, Zlatin Zlatev ${ }^{2}$, Antoaneta Dimitrova ${ }^{2}$ \\ ${ }^{1}$ Trakia University of Stara Zagora, Faculty of Agriculture, Department of Morphology, \\ Physiology and Animal Nutrition, Section of Meat and Meat Products \\ ${ }^{2}$ Trakia university of Stara Zagora, Faculty of Technics and Technologies, \\ 38 Graf Ignatiev str., 8602, Yambol, Bulgaria, e-mail: tania.gt@abv.bg
}

\begin{abstract}
The purpose of the paper is to present selection of informative color features complexes of object areas of pork. The basic descriptive statistics related to 19 color features from six color models (RGB, HSV, Lab, LCH, XYZ, CMYK) measured by colorimeter are presented in the paper. Comparative analysis of methods for informative feature selection is done by 5 distance methods. The methods used for data analysis are Principal component analysis and Correspondence analysis. Complexes of informative color features are proposed for classification of object areas of pork.

Key words: Colorimeter, Pork color, Color features.
\end{abstract}

\section{INTRODUCTION}

The grading of meat and meat products by their color characteristics necessitates the use of precise and faster procedures for obtaining, processing and interpretation of the most informative complex of features concerning the qualitative characteristics of the objects $[1,8$, 10]. The task of assessing the quality of the features themselves, is closely related to reduction of the number of features used in the identification, thereby greatly reducing the required computational resources without loss of information $[2,6]$.

The first requirement in the ranking of the features is to find a minimal description of the feature space, and the second requirement is to find such features, which are as much as possible less dependent on each other [3,9].

The main goal of this paper is to determine the value of color information features of color models for recognition of object areas on the surface of the pork.

\section{MATERIAL AND METHODS}

For the purpose of the study are used 25 samples pork chops purchased commercially. The color is measured at 5 points for object areas on the surface of meat with meat, fat and bone tissue.

The measurement of the color is realized with a colorimeter, developed at the Department "Electrical Engineering, Electronics and Automation" at the Faculty of "Technics and Technologies" - Yambol, Bulgaria [11]. To adjust the color has been used the methodology presented in [8] by reference Lovibond with serial number 12064.

In Figure 1 is presented a device for measurement of color (colorimeter). The parameters for determining the values of color components are for illumination D65 and observer $10^{\circ}[1,8$, $11]$. 


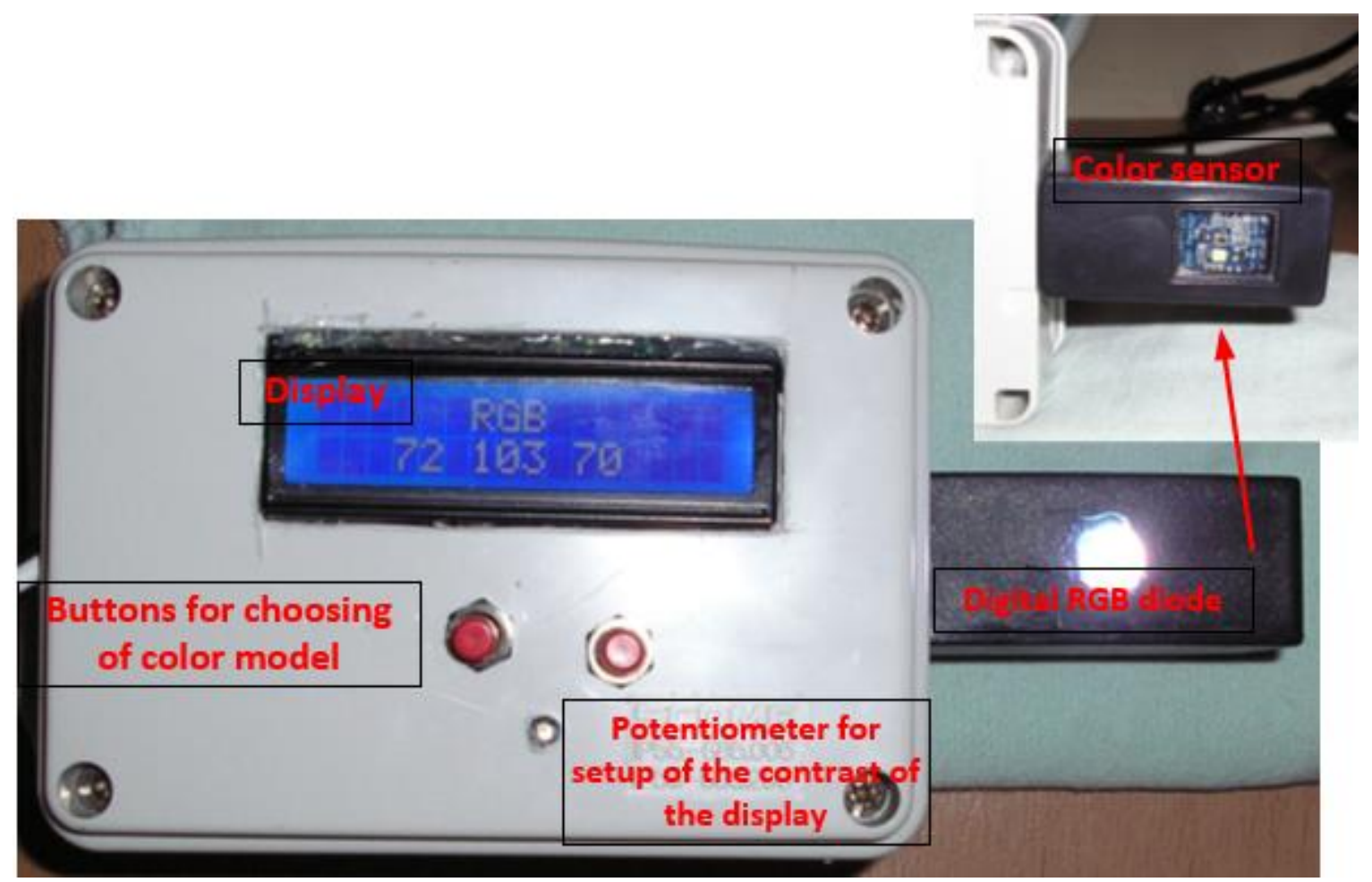

Figure 1. Device for measurement of color

In Table 1 is a description of the investigated functions of the distance between the color components.

Have been used Mahalanobis distance, Euclidean distance, a distance of Manhattan (Cityblock), Chebyshev distance and Fisher discriminant ratio.

Table 1. Distance functions used in the study

\begin{tabular}{|c|c|c|}
\hline Function & Mathematical formula & Description \\
\hline Mahalanobis & $d_{s t}^{2}=\left(x_{s}-y_{t}\right) C^{-1}\left(x_{s}-y_{t}\right)^{\prime}$ & C - covariance matrix \\
\hline Euclidean & $d_{s t}^{2}=\left(x_{s}-y_{t}\right)\left(x_{s}-y_{t}\right)^{\prime}$ & \multirow[b]{2}{*}{$\begin{array}{l}x \text { and } y \text { - the compared } \\
\text { vectors }\end{array}$} \\
\hline Cityblock & $d_{s t}=\sum_{i=1}^{n}\left|x_{s j}-y_{t j}\right|$ & \\
\hline Chebychev & $d_{s t}=\max _{j}\left\{\left|x_{s j}-y_{t j}\right|\right\}$ & max - maximum \\
\hline $\begin{array}{l}\text { Fisher discriminant } \\
\text { ratio }\end{array}$ & $d_{S t}=\frac{(\bar{x}-\bar{y})^{2}}{S D_{x}^{2}+S D_{y}^{2}}$ & SD - standard deviation \\
\hline
\end{tabular}

The resulting distances are processed by methods: Principal Component Analysis (PCA) and Correspondence Analysis (CA) [4, 5, 7, 12]. With these methods are determined the informative color features.

\section{RESULTS AND DISCUSSION}

Table 2 shows the systematized results for averages of color components from six color models. Referred are average values and standard deviation of each color component for each of researches areas on the surface of the meat - fatty, meat and bone tissues.

IRTTIE Vol. 4, No. 4, 2016 ISSN 1314-8788 (print), ISSN 1314-8796 (online), doi: 10.15547/artte.2016.04.008 
Table 2. Mean values and standard deviation of the color features for object areas

\begin{tabular}{|c|c|c|c|c|}
\hline \multicolumn{2}{|c|}{ Color component } & Meat tissue & Fat tissue & Bone tissue \\
\hline \multirow{3}{*}{ RGB } & $\mathbf{R}$ & $168,800 \pm 8,061$ & $204,352 \pm 19,515$ & $171,186 \pm 54,336$ \\
\hline & G & $104,142 \pm 10,861$ & $153,598 \pm 25,178$ & $107,406 \pm 57,372$ \\
\hline & B & $91,428 \pm 15,454$ & $128,976 \pm 32,596$ & $94,394 \pm 50,857$ \\
\hline \multirow{3}{*}{ HSV } & $\mathbf{H}$ & $0,063 \pm 0,186$ & $0,057 \pm 0,060$ & $0,132 \pm 0,288$ \\
\hline & $\mathbf{S}$ & $0,459 \pm 0,083$ & $0,373 \pm 0,125$ & $0,464 \pm 0,206$ \\
\hline & $\mathbf{V}$ & $0,662 \pm 0,032$ & $0,801 \pm 0,077$ & $0,671 \pm 0,213$ \\
\hline \multirow{3}{*}{ Lab } & $\mathbf{L}$ & $130,508 \pm 8,968$ & $173,216 \pm 21,411$ & $133,540 \pm 52,310$ \\
\hline & $\mathbf{a}$ & $153,654 \pm 3,684$ & $145,464 \pm 6,080$ & $152,762 \pm 12,839$ \\
\hline & b & $146,774 \pm 5,933$ & $149,022 \pm 8,557$ & $147,936 \pm 10,289$ \\
\hline \multirow{3}{*}{ LCH } & $\mathbf{L}$ & $51,180 \pm 3,517$ & $67,928 \pm 8,396$ & $52,369 \pm 20,514$ \\
\hline & C & $32,047 \pm 5,688$ & $27,438 \pm 10,211$ & $32,137 \pm 15,762$ \\
\hline & $\mathbf{H}$ & $35,432 \pm 7,300$ & $49,453 \pm 6,044$ & $46,683 \pm 50,700$ \\
\hline \multirow{3}{*}{$X Y Z$} & $\mathbf{X}$ & $7963,494 \pm 1053,160$ & $14105,170 \pm 3669,728$ & $9920,870 \pm 6169,843$ \\
\hline & $\mathbf{Y}$ & $6419,796 \pm 1056,172$ & $12786,214 \pm 3819,021$ & $8454,698 \pm 5910,425$ \\
\hline & $\mathbf{Z}$ & $3190,112 \pm 1043,706$ & $6924,116 \pm 3389,517$ & $4454,212 \pm 3583,852$ \\
\hline \multirow{4}{*}{ CMYK } & C & $23,160 \pm 3,504$ & $11,652 \pm 5,692$ & $27,610 \pm 28,804$ \\
\hline & M & $142,196 \pm 16,514$ & $91,170 \pm 26,519$ & $138,888 \pm 61,399$ \\
\hline & $\mathbf{Y}$ & $117,164 \pm 24,637$ & $96,288 \pm 35,864$ & $119,738 \pm 53,405$ \\
\hline & $\mathrm{K}$ & $77,616 \pm 9,447$ & $41,742 \pm 18,829$ & $75,990 \pm 54,348$ \\
\hline
\end{tabular}

Table 3. Distances for object areas by color features

\begin{tabular}{|c|c|c|c|c|c|c|c|c|c|c|c|c|c|c|c|}
\hline \multirow{2}{*}{$\underbrace{\frac{0}{0}}_{\substack{\frac{0}{0} \\
\frac{0}{0} \\
\frac{0}{0} \\
\frac{0}{0}}}$} & \multicolumn{3}{|c|}{ Mahalanobis } & \multicolumn{3}{|c|}{ Euclidian } & \multicolumn{3}{|c|}{ Cityblock } & \multicolumn{3}{|c|}{ Chebychev } & \multicolumn{3}{|c|}{$\begin{array}{c}\text { Fisher } \\
\text { discriminant ratio }\end{array}$} \\
\hline & $\begin{array}{l}\frac{\pi}{\pi} \\
\frac{\pi}{\pi} \\
\frac{\pi}{\pi} \\
\sum\end{array}$ & 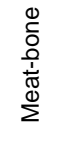 & $\begin{array}{l}\frac{0}{0} \\
\frac{0}{0} \\
\frac{0}{1} \\
\frac{1}{\leftarrow}\end{array}$ & $\begin{array}{l}\frac{\pi}{\pi} \\
\frac{1}{\pi} \\
\frac{\pi}{\pi} \\
\sum\end{array}$ & 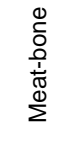 & $\begin{array}{l}0 \\
\stackrel{0}{0} \\
\frac{0}{1} \\
\frac{1}{\pi} \\
\stackrel{1}{L}\end{array}$ & $\begin{array}{l}\frac{ \pm}{\pi} \\
\frac{1}{\pi} \\
\frac{\pi}{\pi} \\
\sum\end{array}$ & 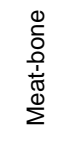 & 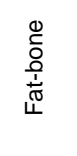 & 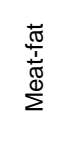 & 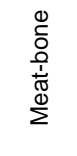 & 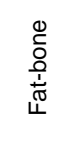 & 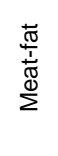 & 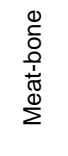 & $\begin{array}{l}\stackrel{0}{0} \\
\frac{0}{0} \\
\frac{0}{1} \\
\stackrel{\leftarrow}{\leftarrow}\end{array}$ \\
\hline $\mathbf{R}$ & 1,78 & 1,77 & 1,78 & 25,57 & 61,69 & 67,65 & 31,26 & 68,86 & 81,92 & 23,92 & 60,36 & 63,57 & 2,84 & 0,00 & 0,33 \\
\hline $\mathbf{G}$ & 1,75 & 1,75 & 1,78 & 33,17 & 67,36 & 76,03 & 40,37 & 75,83 & 92,99 & 31,05 & 65,73 & 71,16 & 3,25 & 0,00 & 0,54 \\
\hline B & 1,76 & 1,76 & 1,77 & 43,74 & 62,88 & 74,73 & 54,46 & 74,61 & 94,65 & 40,53 & 60,11 & 67,82 & 1,08 & 0,00 & 0,33 \\
\hline $\mathbf{H}$ & 0,70 & 1,07 & 0,90 & 0,10 & 0,27 & 0,21 & 0,10 & 0,28 & 0,21 & 0,10 & 0,26 & 0,20 & 0,00 & 0,04 & 0,07 \\
\hline $\mathbf{S}$ & 1,79 & 1,75 & 1,73 & 0,19 & 0,26 & 0,28 & 0,24 & 0,32 & 0,36 & 0,17 & 0,24 & 0,25 & 0,33 & 0,00 & 0,14 \\
\hline V & 1,78 & 1,77 & 1,78 & 0,10 & 0,24 & 0,27 & 0,12 & 0,27 & 0,32 & 0,09 & 0,24 & 0,25 & 2,84 & 0,00 & 0,33 \\
\hline $\mathbf{L}$ & 1,76 & 1,75 & 1,79 & 28,21 & 61,47 & 68,23 & 34,13 & 68,87 & 83,80 & 26,48 & 60,08 & 63,70 & 3,38 & 0,00 & 0,49 \\
\hline $\mathbf{a}$ & 1,76 & 1,76 & 1,73 & 8,69 & 15,42 & 16,31 & 10,73 & 17,99 & 20,59 & 8,03 & 14,78 & 14,97 & 1,33 & 0,00 & 0,26 \\
\hline $\mathbf{b}$ & 1,79 & 1,78 & 1,73 & 12,80 & 14,47 & 16,00 & 16,37 & 18,45 & 21,20 & 11,47 & 13,03 & 13,72 & 0,05 & 0,01 & 0,01 \\
\hline $\mathbf{L}$ & 1,76 & 1,75 & 1,79 & 11,06 & 24,11 & 26,76 & 13,38 & 27,01 & 32,86 & 10,39 & 23,56 & 24,98 & 3,38 & 0,00 & 0,49 \\
\hline C & 1,78 & 1,77 & 1,72 & 14,24 & 19,76 & 21,92 & 17,79 & 23,94 & 28,72 & 13,10 & 18,59 & 19,21 & 0,16 & 0,00 & 0,06 \\
\hline $\mathbf{H}$ & 1,74 & 1,47 & 1,36 & 11,63 & 30,62 & 29,39 & 14,55 & 34,87 & 32,70 & 10,61 & 29,23 & 28,40 & 2,19 & 0,05 & 0,00 \\
\hline$X$ & 1,75 & 1,74 & 1,80 & 4,56 & 7,31 & 8,89 & 5,32 & 8,19 & 11,28 & 4,37 & 7,15 & 8,05 & 2,59 & 0,10 & 0,34 \\
\hline $\mathbf{Y}$ & 1,73 & 1,73 & 1,79 & 4,69 & 6,97 & 8,74 & 5,43 & 7,80 & 11,05 & 4,51 & 6,82 & 7,91 & 2,58 & 0,11 & 0,38 \\
\hline $\mathbf{Z}$ & 1,73 & 1,74 & 1,77 & 4,16 & 4,42 & 6,17 & 4,89 & 5,14 & 7,82 & 3,99 & 4,26 & 5,49 & 1,11 & 0,11 & 0,25 \\
\hline C & 1,77 & 1,72 & 1,72 & 8,24 & 28,90 & 30,05 & 10,36 & 31,85 & 34,24 & 7,49 & 28,28 & 29,02 & 2,96 & 0,02 & 0,30 \\
\hline $\mathbf{M}$ & 1,77 & 1,75 & 1,75 & 38,55 & 73,23 & 78,58 & 48,63 & 85,36 & 97,65 & 34,92 & 70,33 & 72,85 & 2,67 & 0,00 & 0,51 \\
\hline $\mathbf{Y}$ & 1,78 & 1,75 & 1,74 & 53,77 & 68,72 & 76,53 & 69,55 & 85,57 & 98,63 & 47,85 & 63,73 & 68,53 & 0,23 & 0,00 & 0,13 \\
\hline $\mathrm{K}$ & 1,78 & 1,77 & 1,78 & 25,80 & 62,09 & 67,13 & 32,08 & 70,36 & 80,92 & 23,80 & 60,41 & 63,26 & 2,90 & 0,00 & 0,35 \\
\hline
\end{tabular}

By the presented methods for measuring the distance are defined distances between vectors of each color component between the two areas - meat-fat, meat-bone and fat-bone. The obtained results are presented in Table 3 . The resulting distances are processed by method Principal component analysis.

Using the distances - Euclidean, Manhattan, Fischer and Chebyshev according to the method PCA, the color features can not be ranked by informativeness. This ranking is possible by using the Mahalanobis distance. 


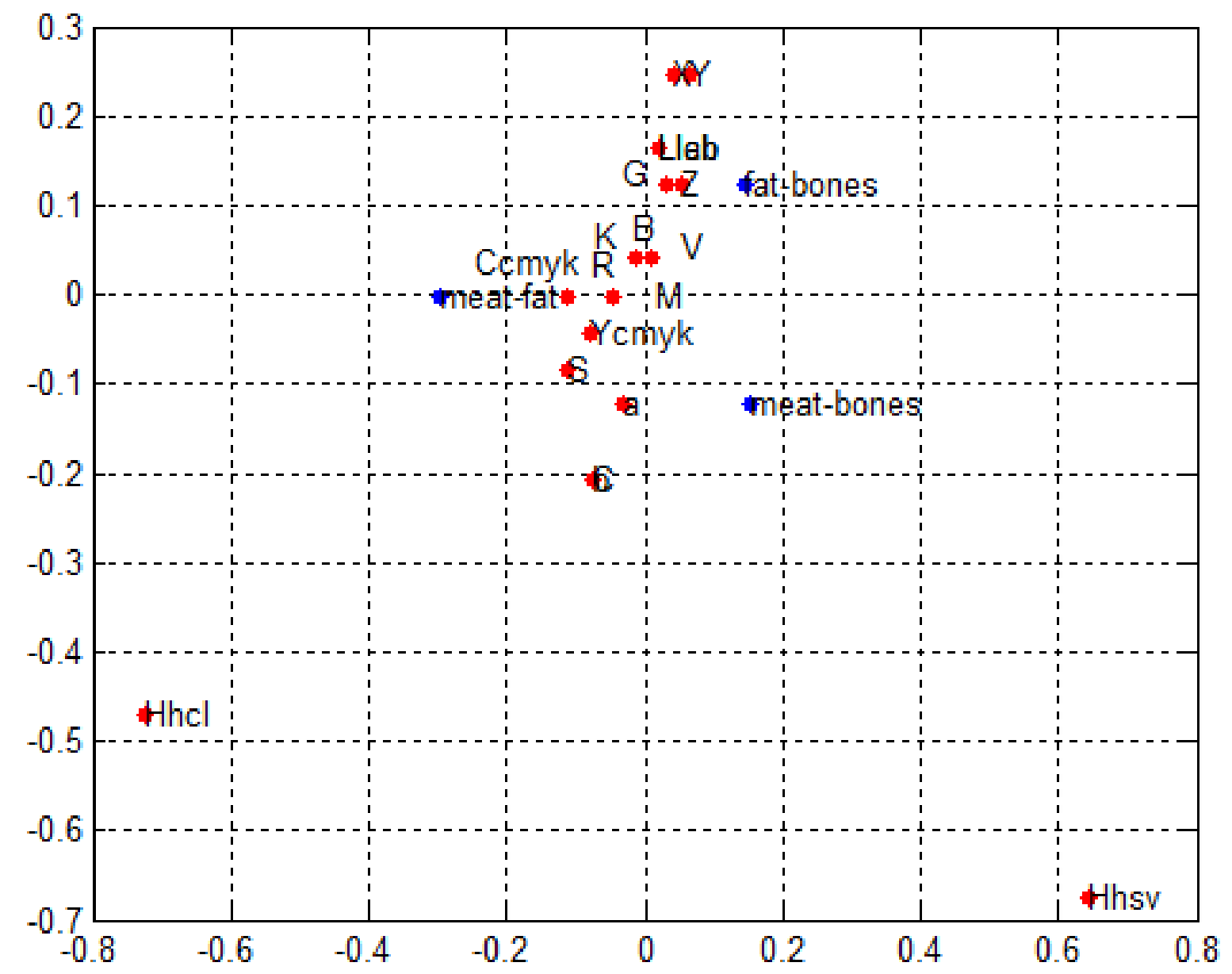

Figure 2.

Results from Principal component analysis for Mahalanobis distance

Figure 2 presents the results of an Principal component analysis using Mahalanobis distance. From this figure it is apparent that $\mathrm{H}$ color component from $\mathrm{HCL}$ and $\mathrm{HSV}$ color model can not be used for the separation of object areas of pork, as apparently is remote from areas and the others color components.

The second method in which they are processed the results for the distances between vectors of color features is Correspondence analysis. In this case, the distance of Mahalanobis not relevant for the evaluation of the informative value of the color features.

Whichever method is used to measure the distance between two vectors as in PCA method $\mathrm{H}$ component from $\mathrm{HCL}$ and $\mathrm{HSV}$ color model is not applicable for the separation of object areas on the surface of the pork.

In Figures 3, 4, 5 and 6 are presented results of Correspondence analysis. 


\section{IRTTIE Ipplied Researrohes in Technics, Technologies and Bducition Journal of the Faculty of Technics and Technologies, Trakia University https://sites.google.com/a/trakia-uni.bg/artte/}

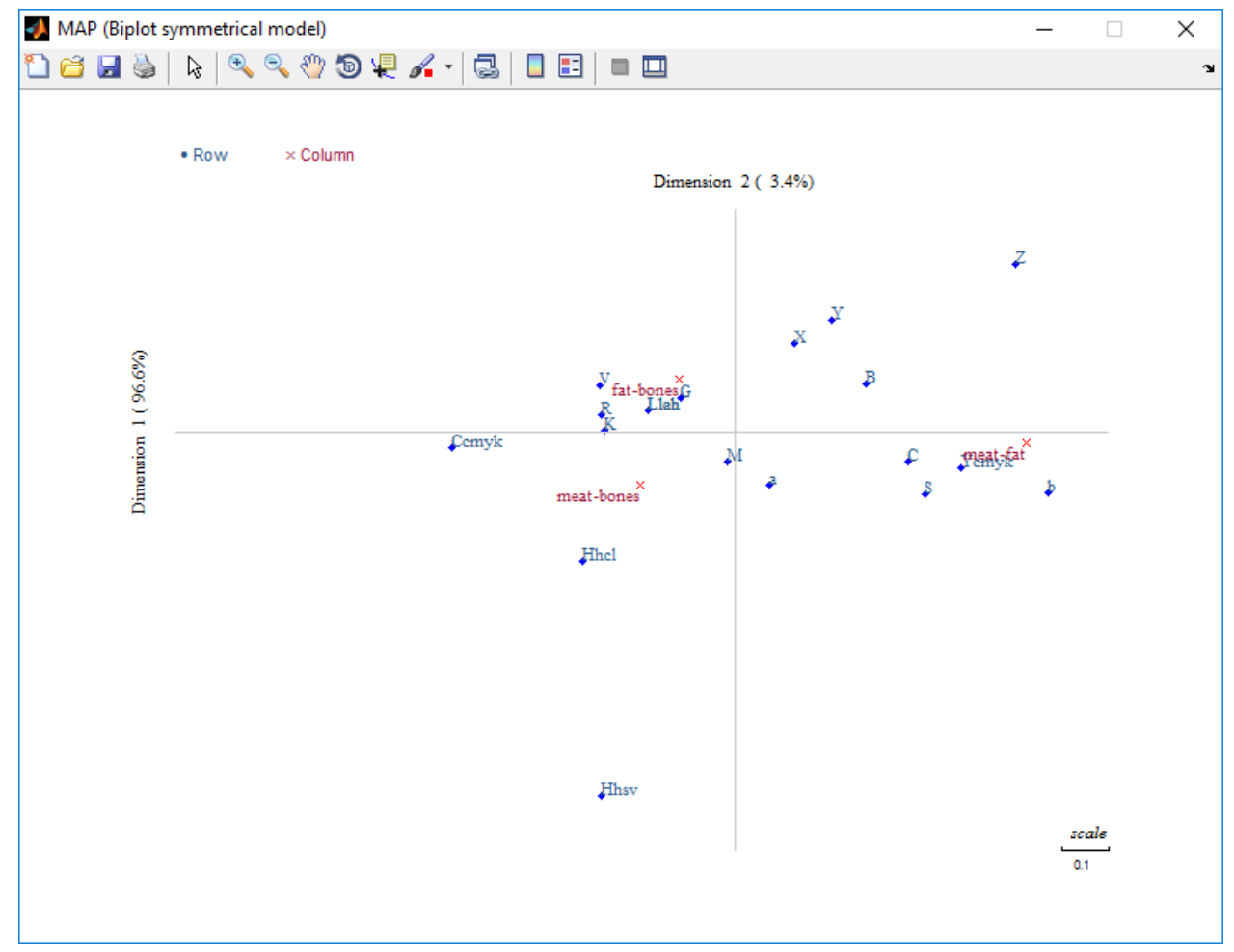

Figure 3. CA for Euclidean distance

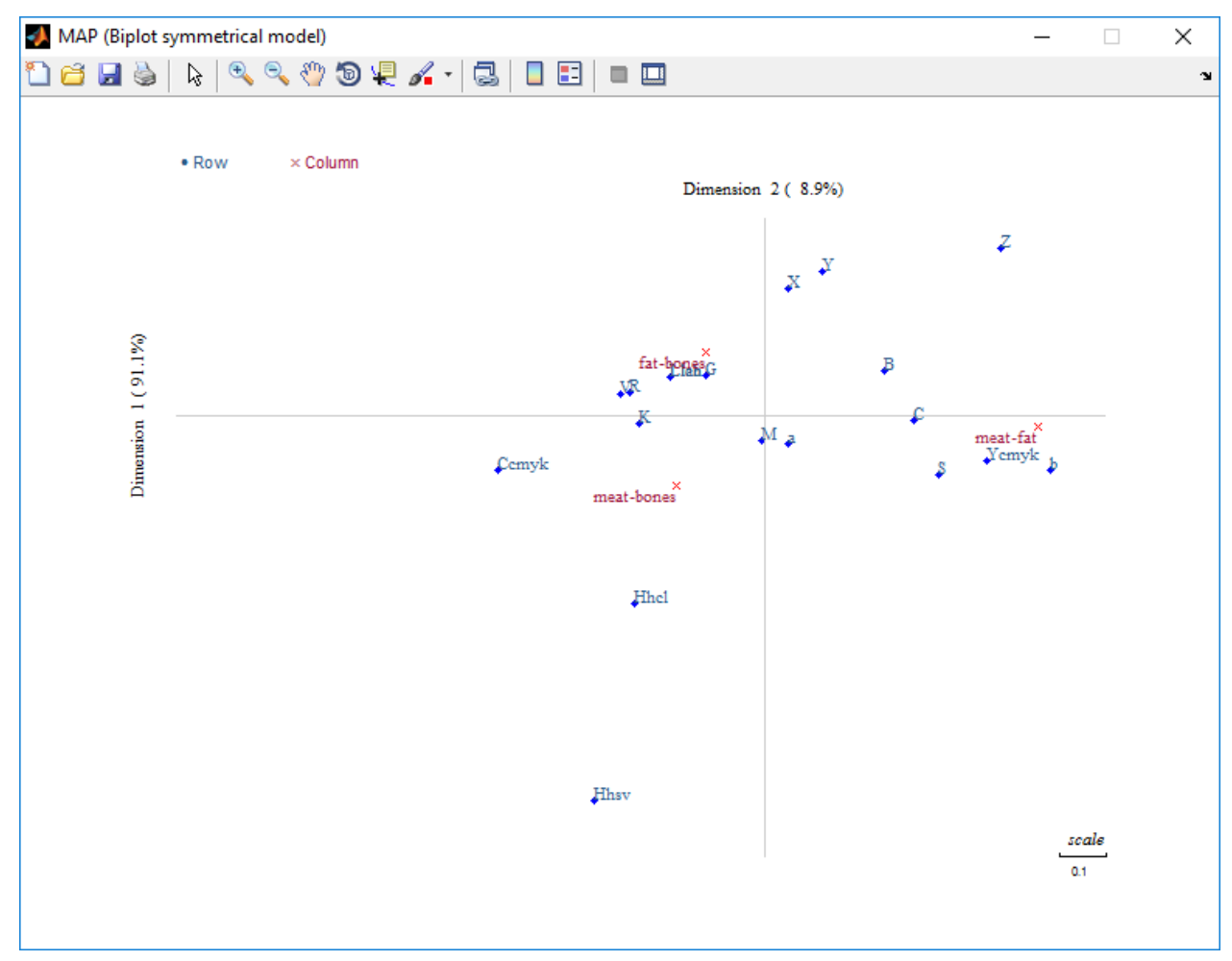

Figure 4. CA for Cityblock distance

IRTTIE Vol. 4, No. 4, 2016 ISSN 1314-8788 (print), ISSN 1314-8796 (online), doi: 10.15547/artte.2016.04.008 


\section{IRTTIE Ipplied Researrothes in Technics, Technologies and Bducition Journal of the Faculty of Technics and Technologies, Trakia University https://sites.google.com/a/trakia-uni.bg/artte/}

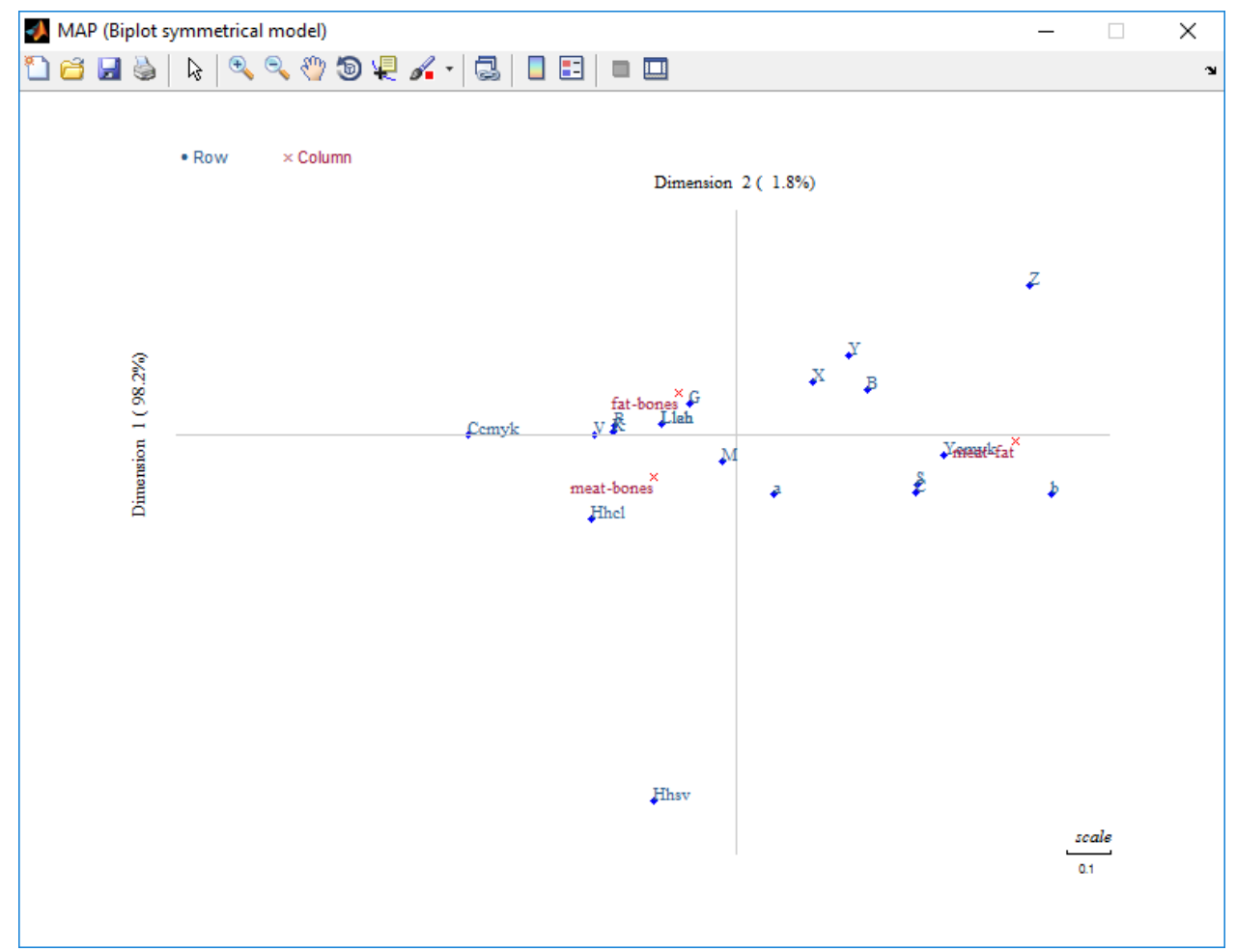

Figure 5. CA for Chebichev distance

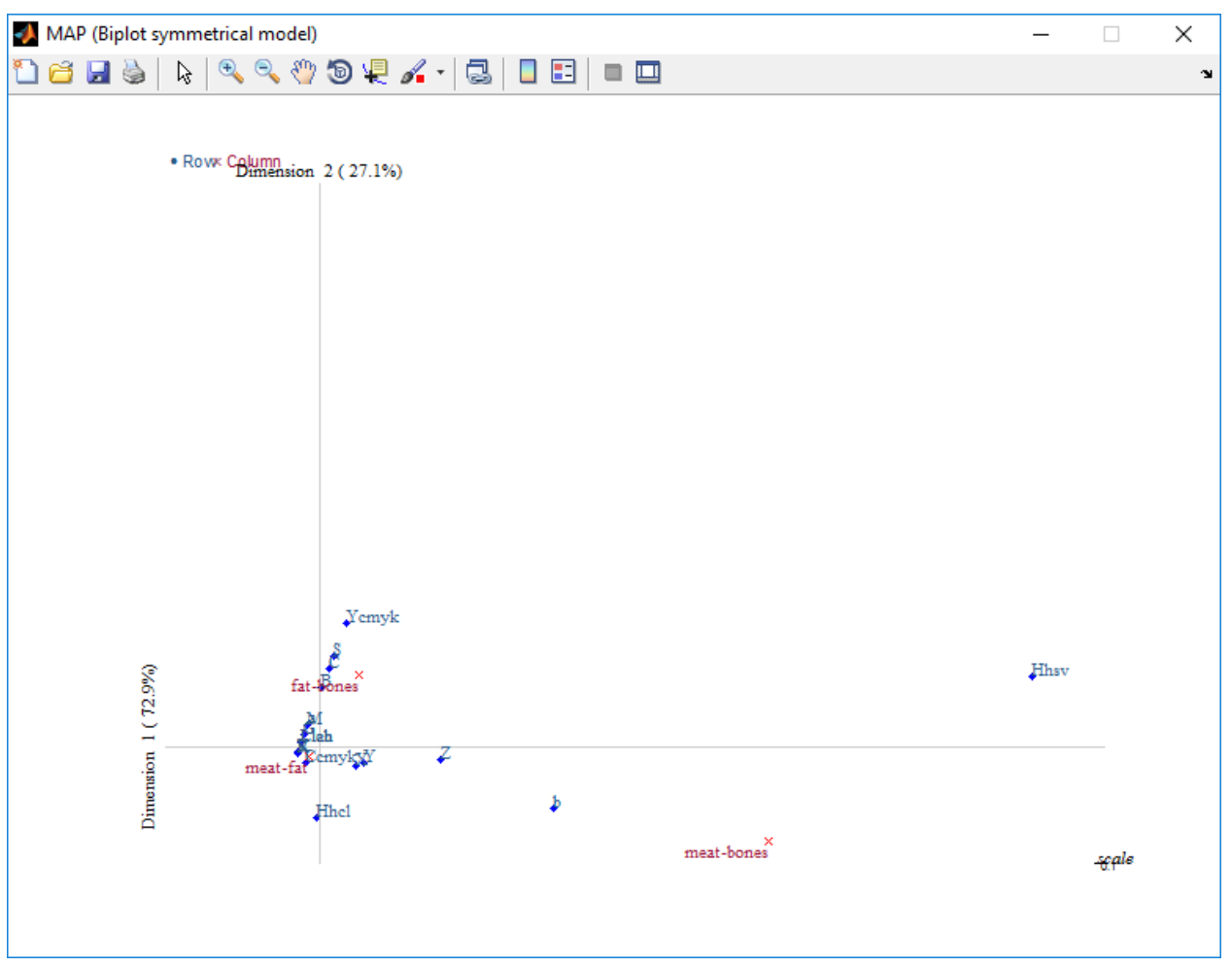

Figure 6. CA for Fisher discriminant ratio

IRTTIE Vol. 4, No. 4, 2016 ISSN 1314-8788 (print), ISSN 1314-8796 (online), doi: 10.15547/artte.2016.04.008 
Table 4 summarizes the results of the selection of color features by methods Principal components analysis and Correspondence analysis. For baseline data were used distances determined by established appropriate methods - Mahalanobis, Euclidean, Manhattan, Chebyshev and Fisher distances. The data are grouped according to the method of valuation of distances and object areas such specified obtained informative color components.

Table 4. Summary analysis of research results

\begin{tabular}{|l|l|c|c|c|}
\hline $\begin{array}{c}\text { Method for data } \\
\text { analysis }\end{array}$ & Distance & Meat-fat & Meat-bone & Fat-bone \\
\hline $\begin{array}{l}\text { Principal } \\
\text { component } \\
\text { analysis }(\mathrm{PCA})\end{array}$ & Mahalanobis & $\begin{array}{c}\mathrm{C}_{\mathrm{CMYK}} ; \mathrm{Y}_{\mathrm{CMYK}} ; \\
\mathrm{K}_{\mathrm{CMYK}} ; \mathrm{R}_{\mathrm{RGB}} ; \\
\mathrm{Y}_{\mathrm{CMYK}} ; \mathrm{M}_{\mathrm{CMYK}} ; \\
\mathrm{B}_{\mathrm{RGB}}\end{array}$ & - & $\mathrm{L}_{\mathrm{Lab}} ; \mathrm{G}_{\mathrm{RGB}} ; \mathrm{Z}_{\mathrm{XYZ}}$ \\
\hline \multirow{2}{*}{$\begin{array}{l}\text { Correspondence } \\
\text { analysis }(\mathrm{CA})\end{array}$} & Euclidean & $\begin{array}{c}\mathrm{Y}_{\mathrm{CMYK}} ; \mathrm{b}_{\mathrm{Lab}} ; \mathrm{S}_{\mathrm{HSV}} ; \\
\mathrm{C}_{\mathrm{CMYK}}\end{array}$ & $\mathrm{H}_{\mathrm{HCL}}$ & $\begin{array}{c}\mathrm{Y}_{\mathrm{XYZ}} ; \mathrm{L}_{\mathrm{LCH}} ; \mathrm{R}_{\mathrm{RGB}} ; \\
\mathrm{K}_{\mathrm{CMYK}} ; \mathrm{G}_{\mathrm{RGB}}\end{array}$ \\
\cline { 2 - 6 } & CityBlock & $\begin{array}{c}\mathrm{Y}_{\mathrm{CMYK}} ; \mathrm{b}_{\mathrm{Lab}} ; \mathrm{R}_{\mathrm{RGB}} ; \\
\mathrm{K}_{\mathrm{CMYK}} ; \mathrm{G}_{\mathrm{RGB}}\end{array}$ & - & $\begin{array}{c}\mathrm{L}_{\mathrm{LCH}} ; \mathrm{G}_{\mathrm{RGB}} ; \mathrm{V}_{\mathrm{HSV}} ; \\
\mathrm{R}_{\mathrm{RGB}} ; \mathrm{K}_{\mathrm{CMYK}}\end{array}$ \\
\cline { 2 - 6 } & $\begin{array}{c}\mathrm{Y}_{\mathrm{CMYK}} ; \mathrm{S}_{\mathrm{HSV}} ; \mathrm{L}_{\mathrm{Lab}} ; \\
\mathrm{b}_{\mathrm{Lab}}\end{array}$ & $\mathrm{H}_{\mathrm{HCL}}$ & $\begin{array}{c}\mathrm{V}_{\mathrm{HSV}} ; \mathrm{R}_{\mathrm{RGB}} ; \\
\mathrm{K}_{\mathrm{CMYK}} ; \mathrm{L}_{\mathrm{LCH}} ; \mathrm{G}_{\mathrm{RGB}}\end{array}$ \\
\cline { 2 - 6 } & $\begin{array}{l}\text { Fisher discriminant } \\
\text { ratio }\end{array}$ & $\begin{array}{c}\mathrm{C}_{\mathrm{CMYK}} ; \mathrm{X}_{\mathrm{XYZ}} ; \mathrm{Y}_{\mathrm{XYZ}} ; \\
\mathrm{M}_{\mathrm{CMYK}} ; \mathrm{L}_{\mathrm{LCH}}\end{array}$ & - & $\mathrm{B}_{\mathrm{RGB}} ; \mathrm{C}_{\mathrm{LCH}} ; \mathrm{S}_{\mathrm{HSV}}$ \\
\hline
\end{tabular}

\section{CONCLUSION}

The report provides a comparative analysis of several criteria to determine the information value of each color features separately.

Is assessed informativeness of 19 color features that represent average values of the color components of 6 color models (RGB, HSV, Lab, LCH, XYZ, CMYK) in relation to the object areas of pork - meat, fat and bone tissues.

From the analysis of the results, the authors consider that:

- It is established the possibility of reducing the number of the color features. Practically it may be reduced, depending on the method of selection;

- It have been used five distance functions at which it is established that the PCA method can be used for the results of the Mahalanobis distance;

- In the method of Corrspondence analysis can be used other 4 ways to measure the distance without Mahalanobis one;

- Distinguishability of object areas is allowed in meat-fat by 5 color components (Y, S, b, C, and $L$ ), meat-bone tissue by 1 component $H$, fatty-bone tissue by 5 components $(L, R, G$, $\mathrm{K}, \mathrm{V})$.

\section{REFERENCES}

[1] Dankov D. P. Prodanov, Investigation of driver for LED lamp, International scientific conference UNITECH 2015, Gabrovo, ISSN 1313-230X, pp.I-333-I-338 (in Bulgarian).

[2] Georgiev, G., N. Georgieva, Investigation possibilities for the use of free software for data processing used for accurate measurement details through photogrammetry. ARTTE Vol. 2, No. 3, 2014, ISSN 1314-8796, pp. 202-210.

[3] Georgieva K., E. Kirilova, Ts. Georgieva, P. Daskalov, Selection of informative color features complexes from digital images of healthy and diseased vine leaves, ARTTE Vol. 3, No. 4, 2015, ISSN 1314-8796, pp.289-295. 


\section{ART'THE $Y$}

Ipplied Researlohes in Technics, Technologies and Bductition

Journal of the Faculty of Technics and Technologies, Trakia University https://sites.google.com/a/trakia-uni.bg/artte/

[4] Kazlacheva Z., J.llieva, M. Zhekova, P. Dineva, Fashion design on the base of connection between colors and lines, ARTTE Vol. 2, No. 1, 2014, ISSN 1314-8796, pp.54-64.

[5] Kazlacheva, Z., Use of the correspondence analysis in fashion design. Textile and apparel, vol.7, 2011, ISSN 1310-912X, pp.191-196 (in Bulgarian).

[6] Kirilova E., P. Daskalov, R. Tsonev, Ts. Draganova, Selection of colour features for recognition of Fusarium damaged corn seeds, Proceedings of Ruse university, vol.49, iss.3.1, 2009, pp.125-130.

[7] Lorenzo-Seva, U., M. van de Velden, H. Kiers. Simple \& multiple correspondence analysis. http://psico.fcep.urv.cat/utilitats/CorrespondenceAnalysis/index.html (available on 02.07.2015).

[8] Mladenov M., St. Penchev, M. Dejanov, Complex assessment of food products quality using analysis of visual images, spectrophotometric and hyperspectral characteristics.// International Journal of Engineering and Innovative Technology (IJEIT), No Vol. 4, 2015, ISSN 2277-3754, pp.23-32.

[9] Prodanov P., D. Dankov, M. Simeonov, Analysis of reliability on the electronic ballast for compact fluorescent lamp, Proceedings of XVII-th International Symposium on Electrical Apparatus and Technologies SIELA 2012, Sofia 28-30 May 2012, ISSN 1314-6297, pp.254-261.

[10] Ribarski S., A. Genchev, S. Atanasova, Effect of cold storage terms on physicochemical characteristics of Japanese quail (Coturnix coturnix japonica) meat, Agricultural Science and Technology, vol.5, No.1, 2013, pp.126-133.

[11] Zlatev Z., A. Dimitrova, S. Baycheva, Colorimeter based on single-board microcomputer and color sensor, AUTOMATICS AND INFORMATICS'2016, October 4-5, 2016, Sofia, Bulgaria, ISSN 1313-1869, pp.29-32 (in Bulgarian).

[12] Zlatev, Z., G. Shivacheva, A. Dimitrova, M. Vasilev, Analysis of data from sensory evaluation of yogurt. Collection of scientific works of XXIV International conference "Management and quality" for young scientists, 15-16 october 2015, ISSN 1314-4669, pp.128-136 (in Bulgarian). 